\title{
THE EFFECTS OF SALINITY ON THE DISTRIBUTION OF AMPHIPODS IN THE COORONG, SOUTH AUSTRALIA, IN RELATION TO THEIR SALINITY TOLERANCE
}

\author{
by M. I. Kangas \& M. C. Geddes*
}

\begin{abstract}
Summary
KANGAS, M. I. \& GedDES, M. C. (1984) The effects of salinity on the distribution of amphipods in the Coorong, South Australia, in relation to their salinity tolerance. Trans. R. Soc. S. Aust. 108(3), 139-145, 13 December, 1984.

The tolerance of Melita zeylanica and Paracorophium sp. to a range of salinity and temperature combinations was investigated by $\mathrm{LD}_{50}$ analysis and response surface analysis. At the optimum temperature of $18-20^{\circ} \mathrm{C}$, the salinity tolerance of both species was from 1 to $62 \%$; at high and low temperatures, tolerance to high salinity was reduced. Melita zeylanica, Paracorophium sp. and Megamphopus sp. were common in the Coorong, but all species generally were restricted to salinities below $53 \%$. No deleterious effects of salinity on the reproductive condition of populations were identified.
\end{abstract}

KEy WORDS: Melita zeylanica, Paracorophium, Megamphopus, salinity tolerance, amphipods, Coorong, South Australia.

\section{Introduction}

Most investigations of the salinity tolerance of estuarine and coastal marine amphipods have considered tolerance to dilute conditions (Vlasblom \& Bolier 1971; Dorgelo 1974, 1976; Ritz 1980). Few studies have been made on tolerance of amphipods to concentrations greater than seawater (McLusky 1967; Marsden 1980), although amphipods are often important in hypermarine systems (Hedgpeth 1967). In the present study the salinity tolerance of $M$. zeylanica and Paracorophium at various temperatures were examined in the laboratory and the results related to the field distribution of the amphipod species in the Coorong lagoons. In the field study the relative abundance and reproductive status of the amphipod species are investigated to look for possible sublethal effects of salinity and temperature on amphipod populations.

The Coorong is a coastal lagoon system situated in the south east of South Australia (Fig. 1). The Coorong waters show a marked longitudinal salinity gradient which varies in direction and intensity seasonally and from year to year (Noye 1975). In 1982, the Coorong lagoons were hypersaline (Geddes \& Butler, 1984), and this provided the opportunity to investigate the distribution of organisms along a hypermarine salinity gradient. Amphipods form a major part of the macrobenthic fauna and this study investigates the distribution and salinity tolerance of three common species Melita zeylanica Stebbing (Melitidae), Paracorophium sp. (Corophiidae) and Megamphopus sp. (Isaedidae). Melita zeylanica is a cosmpolitan species, commonly found in

* Zoology Department, University of Adelaide, Box 498 G.P.O., Adelaide, S. Aust., 5001. estuarine systems (Croker 1971; Barnard 1972; Griffiths 1973; Krishnan \& John 1974, 1975; Boltt 1975) and has been recorded in Australia from the Peel-Inlet (Potter et al. 1981) and Lucky Bay, Western Australia (Barnard 1972), from the Tuggerah Lakes, New South Wales (Collett et al. 1981), and from the Gippsland Lakes, Victoria (Poore 1982). The other two amphipods are

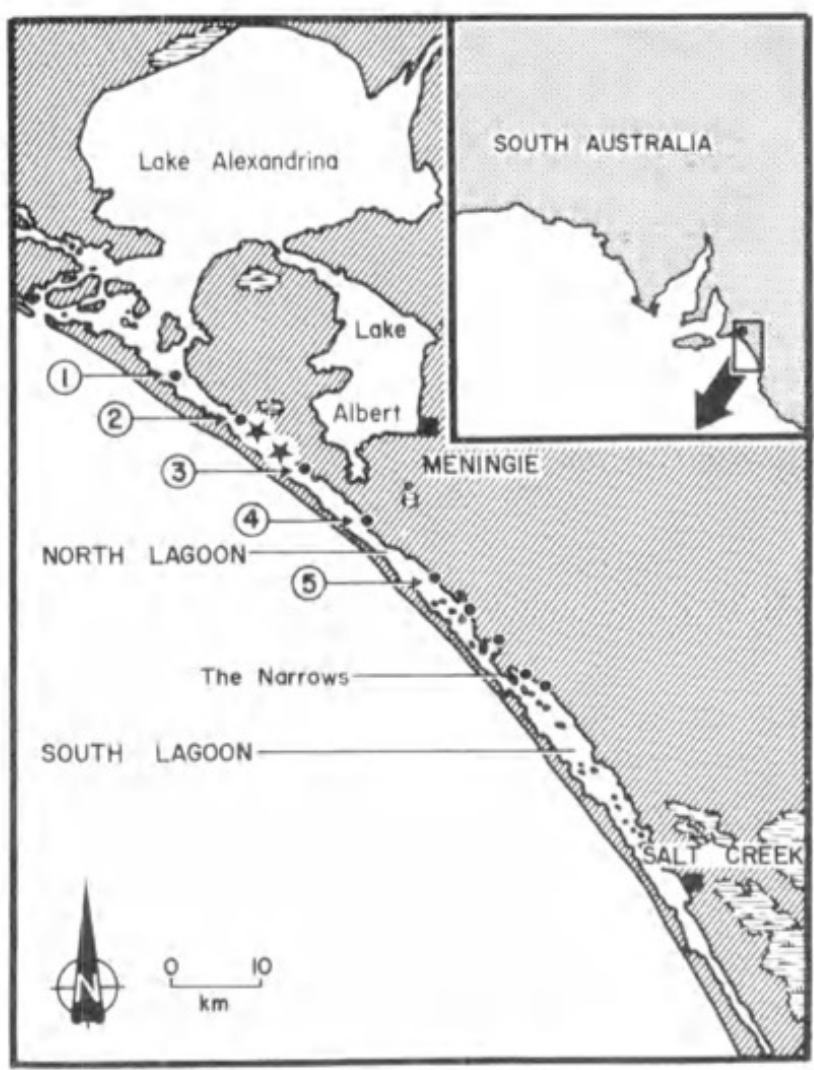

Fig. 1. The Coorong lagoons showing sampling localities $(\bullet)$ and sites where populations of $M$. zeylanica and Paracorophium sp. were collected for salinity tolerance experiments $(*)$. 
undescribed. The genus Paracorophium is endemic to the Southern hemisphere and found in Australia, New Zealand and South America (Barnard \& Karaman 1983). Paracorophium sp. differs from $P$. excavatum Chilton, the only described species known from Australia, in the structure of the third uropod and the number of setae on gnathopods 1 and 2 of the male. Very small numbers of a second undescribed species of Paracorophium were also collected. Neither species is similar to known Paracorophium species (Karaman 1979). No species of Megamphopus have been described from Australia (M. Drummond pers. comm.) but species have been found in abundance in the Tuggerah Lakes, N.S.W. (Collett et al. 1981) and the Gippsland Lakes in Victoria (M. Drummond, pers. comm.). Reference material of the species considered in this paper has been placed in the South Australian Museum, Adelaide (SAM C3924-C3927).

\section{Materials and Methods}

\section{(i) Salinity Tolerance}

Amphipods were collected in March, April and June 1982 from two localities (Fig. 1) at salinities of $51.3,41.9$ and $44 \%$ respectively.

Salinity tolerance was determined at five temperatures for hypersaline conditions $(5.5,14.4,18.5$, $26,32.5^{\circ} \mathrm{C}$ for $M$. zeylanica and $6,14.4,19.5,26$, $30.5^{\circ} \mathrm{C}$, for Paracorophium sp.) and three temperatures for dilute conditions $\left(14,18,25.4^{\circ} \mathrm{C}\right.$ for M. zeylanica $14.4,19.5,27.5^{\circ} \mathrm{C}$ for Paracorophium sp.). Amphipods were acclimated to test temperatures in $35 \%$ (seawater) for two days prior to experimentation.

9-12 amphipods were directly transferred to five salinity dilutions $(0.1-10.5 \%$ ) and ten hypersaline media (38.5-73.9\% ). Dilute media were prepared by mixing seawater and distilled water; hypermarine media were mixtures of seawater and Coorong water. Conductivities $\left(\mathrm{K}_{25}\right)$ were measured with a Radiometer CDM2e Conductivity Meter and total dissolved solids (TDS) calculated by a regression provided in Williams (1966). This regression was developed for saline lake waters but comparison of dried TDS for samples from the Coorong with values calculated from conductivity via the Williams equation showed very close agreement (Geddes \& Butler, 1984). This is to be expected considering the similar nature of ionic dominance in Coorong water and that of Australian salt lakes (Williams \& Buckney 1976). The TDS values were used as a measure of salinity.

At all salinity-temperature combinations, adult individuals were used without regard to sex.
Gentle aeration and a light/dark regime of 12 hour: 12 hour was maintained but no food was added. Fine debris and filamentous algae was supplied to Paracorophium sp. to enable it to construct tubes (considerable mortality was experienced when this tube dwelling species was kept in clear water). The number of animals surviving were counted at 6 and 24 hours and every 24 hours thereafter for 96 hours. Following Ritz (1980), death was taken as a cessation of pleopodal rhythmic beating motor response to tactile stimulation.

Data were analysed in two ways: determining $\mathrm{LD}_{\text {so }}$ values and fitting response surfaces to survival data. For LD $_{50}$ determination, the dose and response ( $\%$ survival) values were transformed to log dose and logits (Hewlett \& Plackett 1979) and regression equations calculated with the form Y $=\mathrm{a}+\mathrm{bX}$ where $\mathrm{Y}$ is logit +10 . This form allows symmetrical confidence limits to be placed on $\mathrm{LD}_{50}$ values.

The response surfaces were fitted according to a BMDP program Stepwise Logistic Regression (PLR) accessed via the Cyber 173 computer. The PLR estimates the vector of parameters ( $\beta \mathrm{i})$ for the linear logistic model $\mathrm{E}(\mathrm{s} / \mathrm{n})=\mathrm{e}^{\beta \mathrm{x} / 1}+\mathrm{e}^{\beta \mathrm{x}}$ where $s$ is the sum of the binary dependent variable (dead, alive) and $X$ represents the independent variables (salinity, temperature). The parameter $\beta$ i may be expanded to a quadratic $\beta_{0}$ $+\beta_{1} \mathrm{X}_{1}+\beta_{2} \mathrm{X}_{2}+\beta_{3} \mathrm{X}^{2}{ }_{1}+\beta_{4} \mathrm{X}_{2}{ }_{2}+\beta_{5} \mathrm{X}_{1} \mathrm{X}_{2}$ where $X_{1}$ is the temperature, $X_{2}$ is the salinity, $\beta_{0}$ is a constant, $\beta_{1}$ is the linear effect of temperature, $\beta_{2}$ is the linear effect of salinity, $\beta_{3}$ is the quadratic effect of temperature, $\boldsymbol{\beta}_{4}$ is the quadratic effect of salinity and $\beta_{3}$ is the interaction effect between temperature and salinity. Contour lines for specified percent survival were then plotted.

\section{(ii) Field Observations}

A series of offshore stations (Fig. 1) were sampled in the North Lagoon of the Coorong at approximately monthly intervals from January 1982-March 1983. The northern end of the South Lagoon was sampled in August 1982 (Fig. 1). At each station, surface temperatures and water samples were taken. Amphipods were collected by towing a trawl net $(160 \mu \mathrm{m})$ through algal beds for 5-10 minutes. The samples were returned to the laboratory, sorted, preserved in $10 \%$ formalin and identified. One hundred randomly selected individuals were identified to record species composition and relative abundance; within each species, sex ratio, female reproductive condition, and egg number were noted. 


\section{(i) Salinity Tolerance}

\section{Results}

Tables 1 and 2 summarise results found through logil analysis for $M$. zeylanica and Paracorphium sp. respectively. The lower $\mathrm{LD}_{\text {in }}$ value for $M$. zeylanica and Paracorophium sp. is $1.0 \%$ and the upper $\mathrm{LD}_{\text {so }_{0}}$ value for $M$. zeylanica is $62 \%$ and for Paracorophium sp. is $60.5 \%$, indicating a wide tolerance range for each species. Due to the wide confidence limits, the respective values of $L D_{s a}$ at each temperature trial overlap with the preceding and following values. General trends are that highest $L_{s}$ values occur at medial temperatures while they decrease at both lower and higher temperalures. For $M$. zeylanica at $5.5^{\circ} \mathrm{C}$ the $\mathrm{LD}_{30}$ value is $52 \%$ and at $32.5^{\circ} \mathrm{C}$ is reduced to $49 \%$. For Paracorophium sp. the $L D_{*}$ value is $59 \%$ at $6.0^{\circ} \mathrm{C}$ and $48 \%$ at $30.5^{\circ} \mathrm{C}$.

The contour patlerns for salinity-temperature combinations are shown in Fig. 2. Both species show wide temperature and salinity tolerance with greater than $90 \%$ survival over most of the experimental range. The central region in the confour pattern provides an estimate of optimum conditions (Alderice 1972). The close spacing of the contours indicates relatively low variability of response in the experimental animals.

Temperature and salinity values and the relative abundance of species at stations 1, 2, 3, 4 and 5 (Stations 1, 3, 5, 7 and 9 in Geddes \& Butler, 1984) during the period December 1981-March 1983 are shown in Fig. 3. Low salinities in Dec 1981. presumably the result of freshwater influx from Lake Alexandrina, were followed by an increase in salinity during the summer months, a lowering during April-June and an increase the following summer. At stations 4 and 5 highest recorded salinities were $68 \%$ and $82 \%$ in January 1983. Surface temperature teached $27^{\circ} \mathrm{C}$ in summer and the minimum was $11^{\circ} \mathrm{C}$ in June.

ТАВL. I. Relationship between logii +10 of $\%$ mortality $(x)$ and $\ln K_{2},(y)$ and the calculated $L D_{\text {so }}$ values for $M$. zeylanica for high and low salinities and at various temperatures

\begin{tabular}{|c|c|c|c|c|}
\hline Temp. & Regression Equation & $r^{2}$ & $\begin{array}{c}\mathrm{LD}_{*} \pm 95 \% \\
\text { confidence limits } \\
\left(\mathrm{K}_{2}\right)\end{array}$ & $\begin{array}{l}\text { LD }_{,} \pm 95 \% \\
\text { confidence limits } \\
\text { (Salinity: TDS) }\end{array}$ \\
\hline $5.5 \mathrm{c}$ & $\ln y=3.896+0.036 x$ & 0.744 & $70.18+1.4 .92$ & $51.9 \pm 9.0$ \\
\hline $14.4 \mathrm{c}$ & $\mathrm{I}_{\mathrm{n}} \mathrm{y}=4.382+0.006 x$ & 0.010 & $71.68 \pm 75.60$ & $53.3 \pm 56.9$ \\
\hline $18.5 \mathrm{c}$ & $I_{n} y=4.111+0.025 x$ & 0.731 & $78.49=16.29$ & $61.8 \pm 9.9$ \\
\hline $26.0 \mathrm{c}$ & $\mathrm{I}_{\mathrm{n}} \mathrm{y}=4.168+0.017 x$ & 0.191 & $76.72 \pm 35.19$ & $58.0 \div 23.0$ \\
\hline $32,5 \mathrm{c}$ & $\ln y=3.81+0.04 x$ & 0.682 & $67.47+18.73$ & $49.4 \pm 11.5$ \\
\hline $14.0 \mathrm{~d}$ & $\mathrm{I}_{\mathrm{ri}} \mathrm{y}=4.57-0.376 x$ & 0.947 & $2.25 \pm 6.03$ & $1.3 \pm 3.5$ \\
\hline 18.0d & $I_{n y} y-3.83-0.329 x$ & 0.925 & $1.72 \pm 6.83$ & $1,0 \pm 4.0$ \\
\hline $26.0 d$ & $f_{n} y=4.771-0.356 x$ & 0.834 & $3.36 \geq 28.90$ & $1.9 \pm 18.4$ \\
\hline
\end{tabular}

$c$-intermediate and concentrated media.

d-dilute media.

Тхвцц 2. Relationship between logit +10 of $\%$ morlality $(x)$ and $\ln \mathcal{K}_{\mathrm{p}},(y)$ and the calculated ID values for Paracorophium $s p$. for high and low salinities and at various temperatures

\begin{tabular}{|c|c|c|c|c|}
\hline Temp. & Regression Equation & $r^{2}$ & $\begin{array}{c}\mathrm{LD} \pm 95 \% \\
\text { confidence limits } \\
\left(\mathrm{K}_{2}\right)\end{array}$ & $\begin{array}{l}\mathrm{LD}_{34}+95 \% \\
\text { confidence limits } \\
\text { (Salinity: TDS) }\end{array}$ \\
\hline $6.0 \mathrm{c}$ & $\mathrm{I}_{\mathrm{n}} \mathrm{y}=3.867+0.049 x$ & 0.518 & $78.33 \pm 25.81$ & $59.5+16.3$ \\
\hline $14.4 \mathrm{c}$ & $I_{n y} y-4.092+0.028 x$ & 0. 597 & $79.44 \pm 24.6$ & $60.5+15.4$ \\
\hline $19.5 c$ & $f_{n y} y-4,002+0.037 x$ & 0.610 & $79.21 \pm 23.45$ & $60.3 \pm 14.6$ \\
\hline 26.06 & $\ln y=3.794+0.049 x$ & 0.614 & $72.61 \pm 18.26$ & $54.1 \pm 11.2$ \\
\hline 30.5 & $\ln y-3.749+0.044 x$ & 0.789 & $66.07 \pm 15.39$ & $48.2 \pm 9.3$ \\
\hline 15.01 & $I_{n} y-4.101-0.476 x$ & 0.536 & $0.52 \pm 33.17$ & $0.3+21.5$ \\
\hline $18.0 \mathrm{~d}$ & $l_{n} y=4.136-0.476 x$ & 0576 & $0.54 \pm 30.56$ & $0.3 \pm 19.6$ \\
\hline $27.5 \mathrm{~d}$ & $\mathrm{I}_{\mathrm{n}} \mathrm{y}=4.961-0.442 k$ & 0.640 & $1.72 \pm 26.82$ & $1.0 \div 17.0$ \\
\hline
\end{tabular}

c-imerinediate and concentrated media.

$\mathrm{d}$-dilule media. 

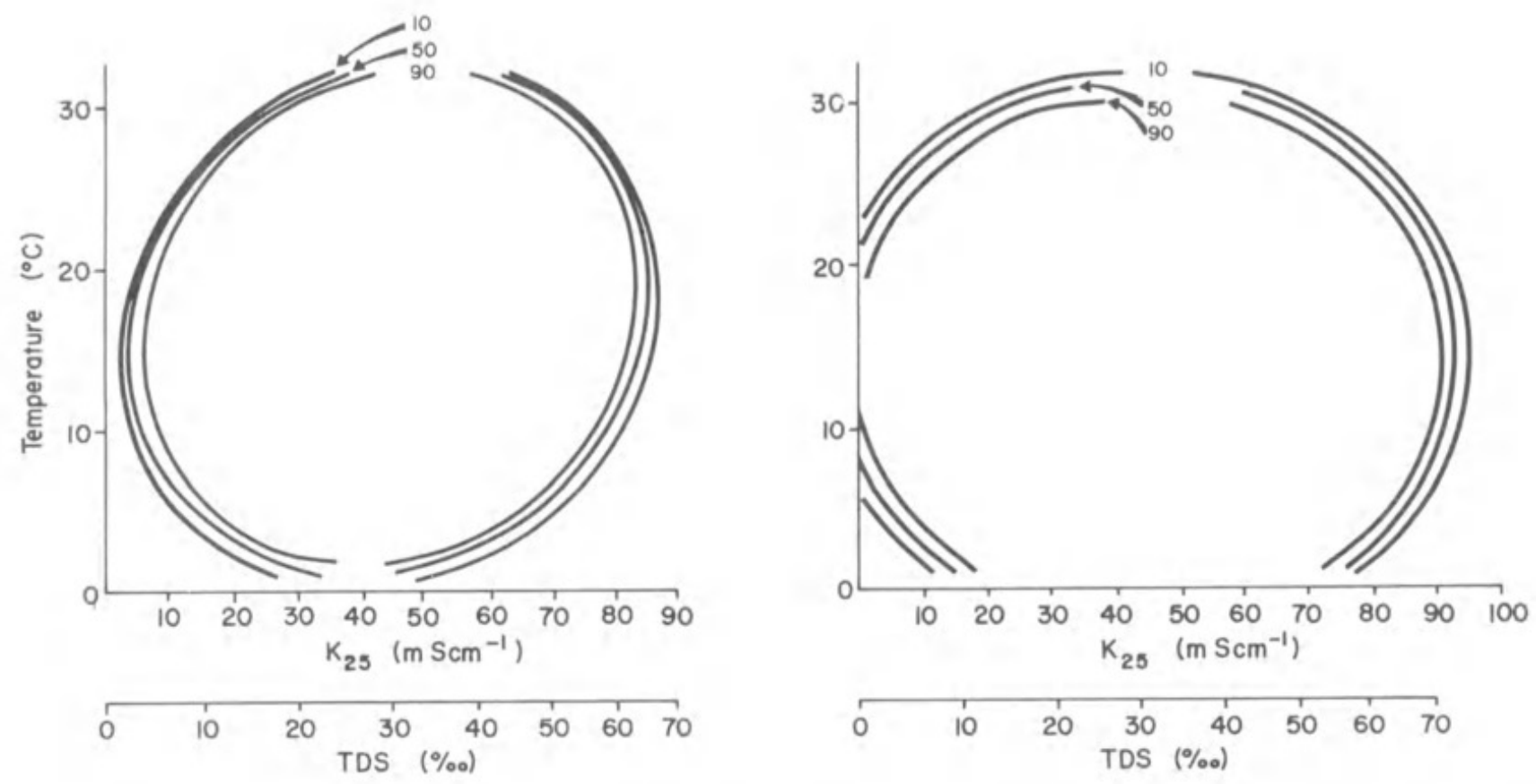

Fig. 2. Estimation of percent survival based on a fitted response surface to observed mortality at $96 \mathrm{hr}$. under 65 conditions of temperature and salinity.

(a) M. zeylanica $\left(\mathrm{e}^{1 / 1}+\mathrm{e}^{\mathrm{i}}=-4.695+.237 \mathrm{~s} \pm .55 \mathrm{tt}-.003 \mathrm{~s}^{2}-.019 \mathrm{t}^{2}-.391 \mathrm{ts}\right)$.
(b) Paracorophium sp. $\left(\mathrm{e}^{\mathrm{i} / 1}+\mathrm{e}^{\mathrm{i}}=-2.183+.18 \mathrm{~s}-.002 \mathrm{~s}^{2}-.016 \mathrm{t}^{2}\right)$.

M. zeylanica, Paracorophium and Megamphopus sp. were found at stations 1,2 and 3 throughout the study period. Paracorophium sp. and Megamphopus sp. occurred at station 4 in Jan. 1982 at a salinity of $60 \%$, but seem to have succumbed to the increasing salinities in the following months. In Nov. and Dec. 1982 Paracorophium sp. reappeared after a period of lowered salinities. Melita zeylanica was collected from station 4 in May when salinity dropped to $51 \%$. Paracorophium sp. was the only species found at station 5 with 5 individuals collected in June. In the South Lagoon salinities were above $80 \%$ and no amphipods were found.

All three species maintained large populations at stations 1, 2 and 3 throughout the study period. Paracorophium sp. generally had the greatest relative abundance and seasonal fluctuations in the abundance of Paracorophium sp. were small. $M$. zeylanica occurred in higher numbers from March-June with a lowering of numbers from Feb.-April 1982 but their abundance was high from June-Nov.

Table 3 documents the effects of salinity and season on the reproductive condition of females; it compares the mean percent ovigerous females and the mean egg number per ovigerous female for the different stations in "summer" (Jan.-April 1982 and Nov. 1982-March 1983) and "winter" (June-Oct. 1982).

All three species breed throughout the year with similar numbers of ovigerous females being present during the summer and winter months. The percent ovigerous females does not show a consistent change between stations, although a substantial decrease occurs at station 4 for Paracorophium $\mathrm{sp}$. The mean number of eggs per ovigerous female for M. zeylanica was similar between stations and seasons except for a low egg number at station 3 in summer. For Paracorophium sp. and Megamphopus sp. there were often significant differences in egg number between stations, with highest egg number generally recorded at station 2 .

\section{Discussion}

A longitudinal gradient of increasing salinity persisted in the Coorong throughout 1982 with hypersaline conditions being maintained over most regions. In years of high River Murray flow the North Lagoon of the Coorong experiences marked lowering of salinity levels (Noye 1975) and so to persist in this region the fauna must be able to tolerate both estuarine and hypermarine conditions. This may limit species richness. In the event, amphipods in the Coorong form a simple assemblage with only three common species. In comparison, many estuaries have a much larger assemblage of amphipods (Gable \& Croker 1978; Collet et al. 1981). Although Melita zeylanica, Paracorophium and Megamphopus are found in 

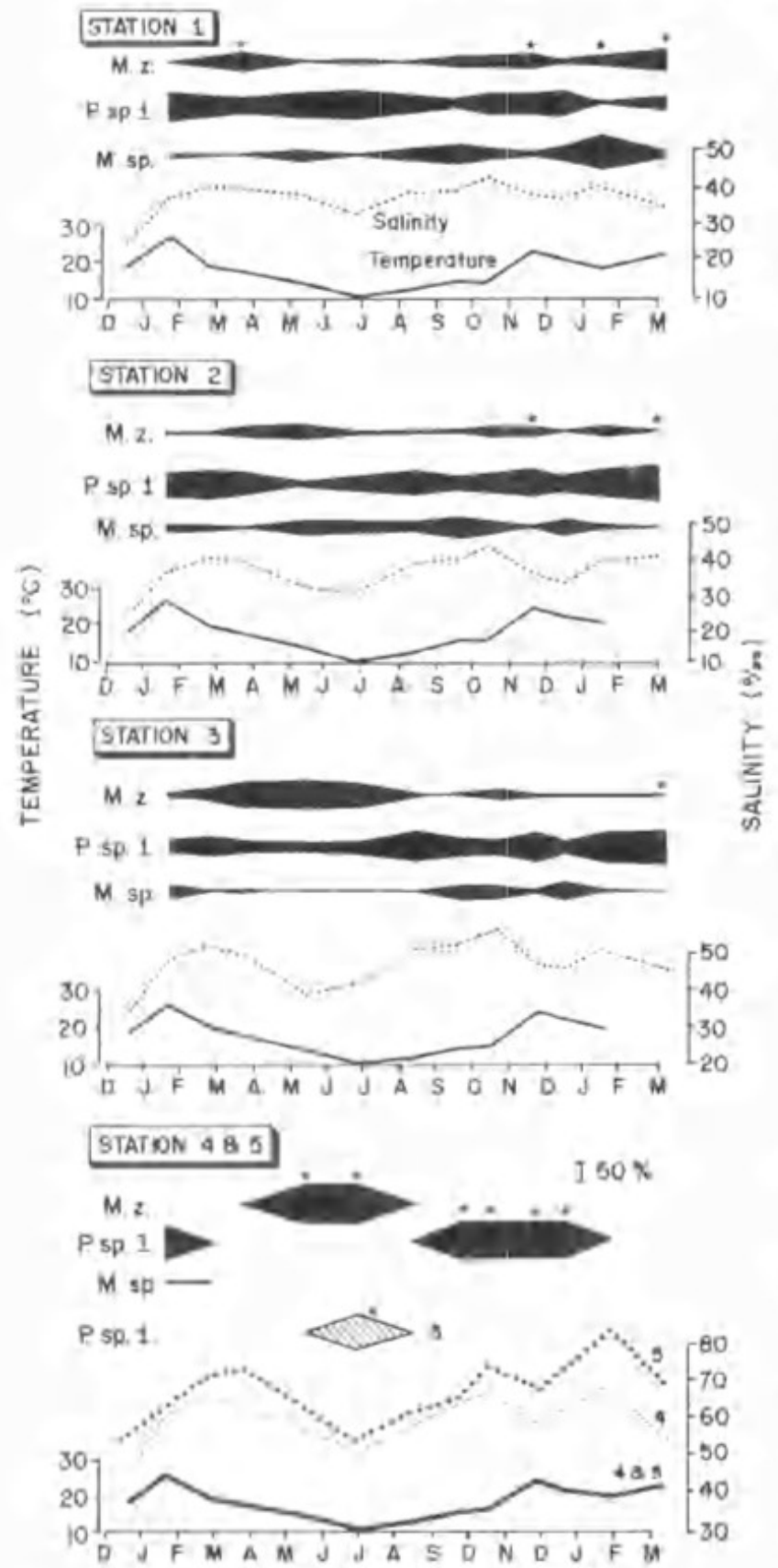

Fig. 3. Seasonal fluefuations in iemperature and salinity ind the relative abundance $(9 \%)$ of $M$ zeylanica $(\mathrm{M}, 7)$ Faracorophaum sp. (P.sp.1) and Alcramphopus (M.sp) from Deci 1981 March 1983. * indicates times when lesy than 20 individuals were found in samples. P.spl I from station 5 is represented by an open block.

estuaries, they appear to be particularly well adapted to the extreme conditions met in coastal lagoon systems. Some or all of these three am. phipods are present in olher Australian coastal lageon systems as previously indicated.

Laboratory studies on $M$. Eeylanica and Paracorophium sp. show that they are eutythermal and euryhaline with a salinity tolerance range of $162 \%$ at the optimal temperature of $18 \%$, Folerance at temperaturc cxtremes $\left(5^{\circ} \mathrm{C}\right.$ and $32.5^{\circ} \mathrm{C}$ ) was somewhat restricted but salinities of $50 \%$ could be tolerated at all temperatures investigated A wide tolerance range is sharaleristic of estuarine or coastal lagoon species which experience fluctuations in envirommental couditious (MeLusky 1967, 1968; Jones 1972; Dorgelo 1976). arid studies on the tolerance of two estuarine amphipods, Orchestia chiliensis (Marsden 1980) and Corophium volutator (McLusky 1967) sbowed a tolerance of $3-51 \%$ and $2-50 \%$ respectively. The present study, and the field records of amphipods from $50-80 \%$ from the Laguna Madre in North America (Hedgpeth 1967), suggest that acclimation in hypermarine environments produced higher sadinity tolerance than is normial for estuarine species.

Most work using response surface analysis has involved fish and large decapods. None has involved amphipods. In the present sudy, response contour lines were more closely spaced than in studies on decapods and fish (Costlow et al. 1962: Kinne 1971: Alderice 1972) indicating little individual variability in response. This may relate to the osmotic bchaviour of the decapods and fish studied which are osmoregulators, while the amphipods in the present study are probably conformers in hypermatine waler. There may be more individual variability in the response of regulators to salinity stress than for conformers.

In 1982, amphipod distribution was not limited by low salinity as is the case in most estuarine systcms (Meadows 1964; McLusky 1968; Mills \& Fish 1980), but the field distribution of all species wats limited by high salinities in the stations fur. ther from the moun of the lagoon. Under the rather stable salinity pattern which persisted throughout 1982, no extensive shanges in amphipod distribution were seen. Generally amphipods were restricted to salinities less than $53 \%$ although sporadic records of a few individuals were made to salinities up to $63 \%$. These values are somewhat lower than found in the laboratory tolerance studies. Field studies in conjunction with laboratory investigations provide informattion on other factors affecting distribution. One factor which may explain differences between Taboratory results and field distributions is the lag time in recruitment of individuals into an area which has only recently become favourable. It is possible that amphipods were absent from southern stations in the winter months when salinities were apparently suitable because previous high stimmer salinities there had exceeded tolerance limils. The young have direct develop- 
TABLE 3. Comparison of percent females ovigerous and mean egg number per ovigerous female between different stations and different "seasons". Figures for percent females ovigerous based on 10-100 females and for egg number on mean of 5-75 brood pouches. The * represents significant differences between mean egg number (Student's t-test, $P<0.05$ ).

\begin{tabular}{|c|c|c|c|c|}
\hline \multirow{3}{*}{ Station } & \multicolumn{3}{|c|}{ M. zeylanica } & \\
\hline & \multicolumn{2}{|c|}{$\%$ Ovigerous } & \multicolumn{2}{|c|}{ Mean \# Eggs } \\
\hline & "Summer" & "Winter" & "Summer" & "Winter" \\
\hline 1 & - & 33.6 & - & 9.2 \\
\hline 2 & 79.7 & 53.3 & * $\{14.6$ & 12.3 \\
\hline 3 & 72.3 & 65.2 & $\{7.4$ & 9.8 \\
\hline \multicolumn{5}{|c|}{ Paracorophium sp. } \\
\hline 1 & 24.7 & 20.0 & $*\{1.9$ & \\
\hline 2 & 50.4 & 25.8 & 4.8 & $\left.5.8 \mathbf{f}^{*}\right\}$ \\
\hline 3 & 32.8 & 35.9 & $\{4.4\}\}$ & $4.9)$ \\
\hline 4 & 6.0 & - & $(2.0\})$ & - \\
\hline \multicolumn{5}{|c|}{ Megamphopus sp. } \\
\hline 1 & 44.5 & 22.7 & 4.3 & 4.3 \\
\hline 2 & 27.5 & 28.7 & $\int^{*}\{7.9$ & 5.5 \\
\hline 3 & 28.0 & 31.0 & * $\{4.2$ & 3.9 \\
\hline
\end{tabular}

ment and so there is no planktonic dispersal phase. Thus, in a system with seasonal and longterm fluctuations in salinity and with animals having poor dispersal abilities, it is possible that there is a time lag between the advent of suitable physico-chemical conditions in an area and the establishment of a viable population.

There were no clear effects of salinity on the reproductive condition of populations. The proportion of ovigerous females and the mean egg number per female showed no seasonal change although summer salinities were considerably higher than those in winter. At stations 1 to 3 there was no major difference in percent ovigerous females but Paracorophium sp. from station 4 showed a marked reduction in the percent ovigerous females. For all species there were some differences in mean egg number between stations, with stations 3 and 4 having lower egg number than station 2 . This may indicate some lowering of reproductive capacity at higher salinities, but the evidence is not conclusive.
The amphipods form a major part of the macrobenthic fauna of the Coorong, and are probably important in food chains leading to fish and birds. High salinities in the Coorong results in nar rowing of the range of distribution and lowering of abundance of amphipods and this may have significant effects on animals further up the food chain.

\section{Acknowledgments}

We thank Julie Francis and Helen Vanderwoude for help with collecting and sorting amphipods, Dr Keith Walker for advice on data analysis and Phil Leppard for advice on computer analysis and in the design of programs. We are grateful to Prof. W. D. Williams and Dr Margaret Drummond for discussions on amphipod taxonomy and distribution. Thanks to Heather Kimber and Sandra Lawson for typing the manuscript and to Ruth Altmann for the art work. This study was supported by an M.S.T. grant which is gratefully acknowledged.

\section{References}

AldericE, D. F. (1972) Factor Combinations. In: O. Kinne (Ed.), "Marine Ecology", Vol. I, Pt. 3, pp. 1659-1772. (Wiley-Interscience: New York.)

BARNARD, J. L. (1972) Gammaridean Amphipoda of Australia, Part 1. Smithsonian Contributions to Zoology 103, 1-327.

- \& KARAMAN, G. S. (1983) Australia as a major evolutionary centre for Amphipoda (Crustacea). In: J. L. Lowry (Ed.) Papers from the Conference on the Biology and Evolution of Crustacea. Australian Museum Memoir 18, 45-61.

Collett, L. C., Collins, A. J., Gibis, P. J. \& West, R. J. (1981) Shallow dredging as a strategy for the control of sublittoral macrophytes: a case study in Tuggerah Lakes, New South Wales. Aust. J. Mar. Freshwater Res. 32, 563-571.

BoLLT, R. E. (1975) The benthos of some southern African lakes. Pt. IV: The benthos of Lagoa Poelela. Trans. R. Soc. S. Afr: 41, 273-282.
Costlow, J. D., Bookout, C. G. \& Monroe, R. (1962) Salinity-temperature effects on the larval development of the crab Panopeus herbstii Milne-Edwards, reared in the laboratory. Physiol. Zool. 35, 79-93.

Croker, R. A. (1971) A new species of Melita from the Marshall Islands, Micronesia. Pac. Sci. 25, 100-108.

DaY, J. H. (1979) The Estuarine Fauna. In: J. H. Day (Ed.), "Estuarine ecology with particular reference to Southern Africa". (A. A. Balkema: Cape Town.)

DoRGElo, J. (1974) Comparative ecophysiology of gammarids from marine, brackish and freshwater habitats, exposed to the influence of salinity-temperature combinations. 1. Effect on survival. Hydrobiol. Bull. 8, 90-108.

(19?6) Salt tolerance in Crustacea and the influence of temperature upon it. Biol. Rev. 51. 255-290.

GABle, M. F. \& CROKER, R. A. (1978) The saltmarsh amphipod Gammarus palustris Bousfield at the northern limit of its distribution. Estuar. cstl. mar. Sci. 6, 225-230. 
Gedoes, M. C. \& Butzer, A. J. (1984) Physicochemical and hiological studies on the Coorong Lagoons, South Australia, and the effect of salinity on the distribution of the macrobenthos. Trans. R, Soc S, Aust. 108(1), $51-62$.

Grintirirs, C. L. (1973) The amphipods of Southern Africa. Part 1. The Gammaridae and Caprellidac of southern Mocambiquc. Amn. S. Afr. Mus. 60, 265-306

HEDGPETH, J. W. (1967) Ecological aspects of the Laguna Madre, a hypersaline estuary. In: G. H. Lauff (Ed.), "Estuaries", pp. 408-419. Am. Assoc. Advan. Scl, Publ. No. 83 .

Hewintt, P. S. \& Plackeit, R. L. (1979) The Interpretation of Quantal Responses in Biology. Ch. 3 (Edward Arnold: London.)

JONEs, M. B. (1972) Effects of salinity on the survival of the Jaera albifons Leach group of species (Crustaces: Isopoda). I. cxp. mar. Biol. Ecol. 9, 231-237.

KARAMAN, G, S. (1979) Revision of the genus Paracorophium Stebb with description of P. chelatum, n. sp. and genus Chactocorophium, n. gen. (Fam. Corophiidae) (contribution to the knowledge of the amphipoda 100) Prir. Glas. Republ. Zavoda Zast. Prir. Muz. Titogradu. $12,87-100$,

KInNr, O. (1971) Salinity: Animals-Invertebrates. In; O. Kinne (Ed.), "Marine Ecology". Vol. 1. Environmental Factors, PI, 11, pp. 821-995. (John Riley: London.)

Krishinan, L. \& JohN, P. A. (1974) Observations on the breeding biology of melita zeylunica Stebbing, a brackish water amphipod. Hydrobiologia 44, 413-430. \&_(1975) Breeding biology of the amphipod Melita zeylanica in a tropical monsoonal lake. Zool. Anz $194,328-334$.

MArspeN, I. D. (1980) Effects of constant and cyclic temperanoes on the salinity tolerance of the estuarine sandhopper Onchestia chilicnsis. Mar. Biol. 59, 211-216.
MCluskY, D. S. (1967) Some effects on the survival. moulting and growth of Corophium volutator, I. Mar. biol. Ass, U.K. 47, 607-617.

(1968) Some effects of salinity on the distribution and abundance of Corophium volutator in the Vihan Estuary. Ibid, 47, 607,617.

MEADow5. R. S. (1964) Experiments on substrate selection by Corophium species: films and bacteria on sand particles. J. exp. Biol. 41, 499-511.

MILIS, A. \& FIsH, J. D. (1980) Effects of salinity and temperalure on Corophium volutator and $C$. arenarium with particular reference to distribution. Marine Biol. 58, 153-161.

NoYE, B. J. (1975) "The Coorong-past, present, future". Publ. No. 39.-1974 revised. (Department of Adult Education, University of Adelaide: Adelaide.)

Poore, G. C. (1982) Benthic communities of the Gippsland Lakes, Victoria. Aust, J. Mar. Freshw. Res. 33, 901-915.

Potier, I. C., Lenanton, R. C. J., Lonergan, N., Chrystal, P., CAPuti, N. \& Grant, C. (1981) "The Fish and Crab Fauna of the Peel-Harvey Estuarine System in Relation to the Presence of Cladophora". Bulletin No. 88 (Department of Conservation and Environment: Western Australia).

RIT\%, D. A. (1980) Tolerance of intertidal amphipods to fluctuating conditions of salinity, $\mathrm{O}$, and copper in Gammarus duebeni and Marinogammarus marinus. I. Mar. Biol. Ass. U.K. 60, 489-498.

Vlasbiom, A. G. \& Bolick, G. (1971) Tolerance of embryos of Marinogammarus marimus and Orchestio gamarella to lower salinities. Neth. J. Sea. Res. 5, $334-341$.

WIILIAMS, W. D. (1966) Conductivity and the concentration of total dissolved solids in Australian lakes. Aust. J. Mur. Freshwaler Res. 17, 169-176.

\& BUCKNEY, R. T. (1976) Chemical composition of some inland surface waters in south, western and northern Australia. Ibid. 27, 379-397. 


\title{
A NEW SPECIES OF CALAMOECIA (COPEPODA: CALANOIDA) FROM SOUTH AUSTRALIA, AND COMMENTS ON THREE CONGENERS
}

\author{
BY I. A. E. BAYLY
}

\section{Summary}

Calamoecia zeidleri sp. nov., a comparatively large species of Calamoecia, is described from fresh waters near Lake Eyre and Oodnadatta. 


\section{$2 \mathrm{BHL}$ Biodiversity Heritage Library}

Kangas, M I and Geddes, Michael C. 1984. "THE EFFECTS OF SALINITY ON THE DISTRIBUTION OF AMPHIPODS IN THE COORONG SOUTH AUSTRALIA IN RELATION TO THEIR SALINITY TOLERANCE." Transactions of the Royal Society of South Australia, Incorporated 108, 139-146.

View This Item Online: https://www.biodiversitylibrary.org/item/128035

Permalink: $\underline{\text { https://www.biodiversitylibrary.org/partpdf/79476 }}$

\section{Holding Institution}

South Australian Museum

\section{Sponsored by}

Atlas of Living Australia

\section{Copyright \& Reuse}

Copyright Status: In copyright. Digitized with the permission of the rights holder.

License: http://creativecommons.org/licenses/by-nc-sa/3.0/

Rights: https://biodiversitylibrary.org/permissions

This document was created from content at the Biodiversity Heritage Library, the world's largest open access digital library for biodiversity literature and archives. Visit BHL at https://www.biodiversitylibrary.org. 